University of Nebraska - Lincoln

DigitalCommons@University of Nebraska - Lincoln

2020

Development of an on-line immunoextraction/entrapment system for protein capture and use in drug binding studies by highperformance affinity chromatography

\author{
Elliott L. Rodriguez \\ University of Nebraska-Lincoln \\ Saumen Poddar \\ University of Nebraska-Lincoln, spoddar@huskers.unl.edu \\ Meera Choksi \\ University of Nebraska-Lincoln \\ David S. Hage \\ University of Nebraska-Lincoln, dhage1@unl.edu
}

Follow this and additional works at: https://digitalcommons.unl.edu/chemistryhage

Part of the Medicinal-Pharmaceutical Chemistry Commons

Rodriguez, Elliott L.; Poddar, Saumen; Choksi, Meera; and Hage, David S., "Development of an on-line immunoextraction/entrapment system for protein capture and use in drug binding studies by highperformance affinity chromatography" (2020). David Hage Publications. 77.

https://digitalcommons.unl.edu/chemistryhage/77

This Article is brought to you for free and open access by the Published Research - Department of Chemistry at DigitalCommons@University of Nebraska - Lincoln. It has been accepted for inclusion in David Hage Publications by an authorized administrator of DigitalCommons@University of Nebraska - Lincoln. 


\title{
Development of an on-line immunoextraction/entrapment system for protein capture and use in drug binding studies by high-performance affinity chromatography
}

\author{
Elliott L. Rodriguez, Saumen Poddar, Meera Choksi, \\ and David S. Hage \\ Chemistry Department, University of Nebraska-Lincoln \\ Corresponding author - D.S. Hage, Chemistry Department, University of Nebraska, \\ Lincoln, NE 68588-0304, USA; email dhage1@unl.edu
}

\begin{abstract}
An on-line purification and entrapment system was developed that could extract a protein from a sample such as serum and entrap this protein within a small column for use in high-performance affinity chromatography. Human serum albumin (HSA) was employed as a model protein for this work. Immunoextraction columns containing polyclonal anti-HSA antibodies were developed to capture and isolate HSA from applied samples. This was followed by the use of a strong cation-exchange column to recapture and focus HSA as it eluted from the immunoextraction columns. The recaptured HSA was entrapped within $1.0 \mathrm{~cm} \times 2.1 \mathrm{~mm}$ I.D. columns containing hydrazide-activated silica and in the presence of oxidized glycogen as a capping agent. The binding and elution properties of HSA on the various components of this system were examined and optimized. The entrapped columns produced by this system were then evaluated for their use in binding studies with several sulfonylurea
\end{abstract}

Published in Journal of Chromatography B 1136 (2020) 121812

doi:10.1016/j.jchromb.2019.121812

Copyright (C) 2019 Elsevier B.V. Used by permission.

Submitted 2 August 2019; revised 18 September 2019; accepted 19 September 2019;

published 30 November 2019. 
drugs. The HSA columns created by this approach typically contained $0.3-0.6 \mathrm{nmol}$ HSA and were stable over several weeks and more than 50-60 sample injections. Drug binding constants could be determined with these columns in $8 \mathrm{~min}$ or less by zonal elution and gave good agreement with literature values. The same system could be used for the capture and entrapment of other proteins by utilizing antibodies against the given target for immunoextraction.

Keywords: Protein immobilization, Entrapment, Immunoextraction, Human serum albumin, Drug-protein binding, High-performance affinity chromatography

\section{Introduction}

Human serum albumin (HSA) is the most abundant transport protein in serum, with an average physiological concentration of $42 \mathrm{~g} / \mathrm{L}$ $[1,2]$. HSA has a fundamental role in the transportation of drugs and many other endogenous ligands in blood [1-3]. Binding to HSA can affect the free and active concentrations of drugs in the circulation, which can in turn impact a drug's absorption, distribution, metabolism, and excretion [1-4].

One approach that can be used to examine the binding of drugs with HSA is high-performance affinity chromatography (HPAC) [5,6]. HPAC is a technique which combines the use of an HPLC support with the selective and reversible interactions that can occur between a given analyte and an immobilized biologically-related binding agent for this target [6]. Columns for this method are often prepared through covalent immobilization of a protein such as HSA $[7,8]$. However, this type of immobilization can lead to multisite attachment or improper orientation of a protein and a loss of activity [7].

Many of these immobilization effects can be avoided by physically entrapping a binding agent such as a protein within a support $[7,8]$. For instance, it has been shown in recent years that this can be accomplished by using the reaction of aldehydes on mildly-oxidized glycogen with a hydrazide-activated support to entrap a soluble protein within HPLC-grade silica (see Fig. 1) [8]. This method has previously been used to immobilize HSA and other serum proteins for use in HPAC and drug binding studies [8-12]. Advantages of this method include the ability of low-to-moderate mass drugs to access the entrapped protein and for protein to remain in a soluble and fully-active form $[8,9]$.

In this study, an on-line immunoextraction and entrapment system will be developed that can isolate a protein such as HSA from samples 


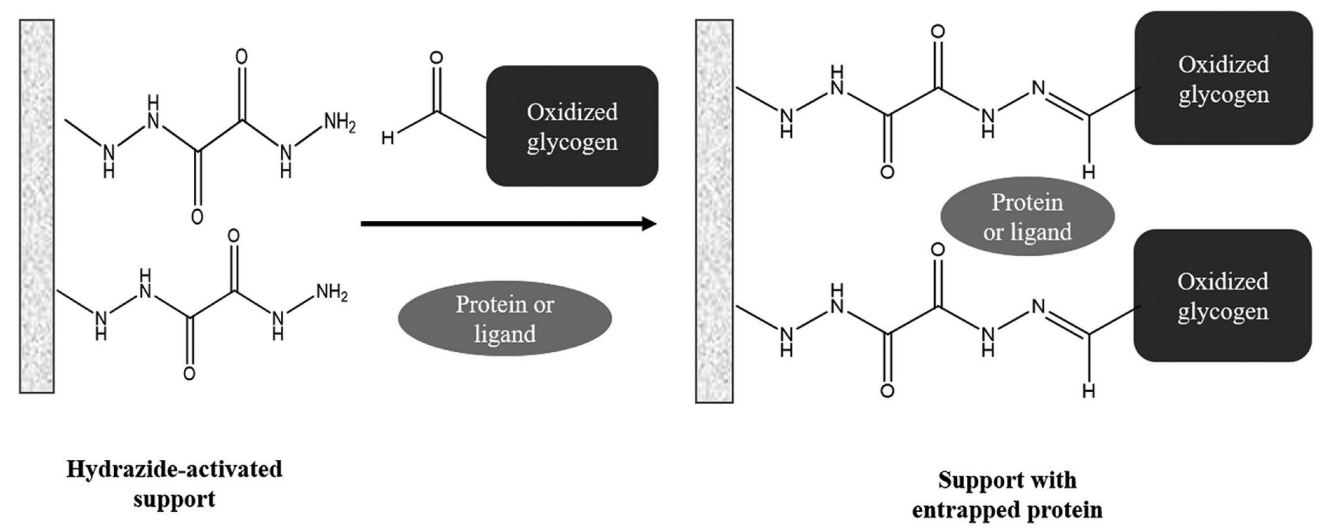

Fig. 1. Entrapment of a protein by using the coupling of oxidized glycogen with hydrazide-activated silica.

like serum and entrap this protein within a small HPAC column (see Fig. 2). This system will use polyclonal anti-HSA antibodies in an immunoextraction column to capture and isolate HSA from an applied sample. A strong cation-exchange (SCX) column will be used to recapture and focus the HSA as this protein elutes from the immunoextraction column. The recaptured HSA will then be entrapped within a small column containing hydrazide-activated silica and in the presence of oxidized glycogen as a capping agent. The binding and elution properties of HSA with the immunoextraction and SCX columns will be examined, along with the ability of the overall system to produce small columns that contain entrapped HSA. The prepared columns will then be evaluated in drug binding studies with the entrapped HSA, using several sulfonylurea drugs as models [13-16]. The results that are obtained with HSA as a model should provide valuable guidelines on the use of such a system and the creation of entrapment-based columns for future work with other proteins.

\section{Materials \& methods}

\subsection{Materials}

The polyclonal anti-HSA antibodies (goat, affinity-purified polyclonal antibodies, product 2080-01) were purchased from VWR (Radnor, PA, USA). The polyclonal anti-HSA goat serum (product A1151), protein G 


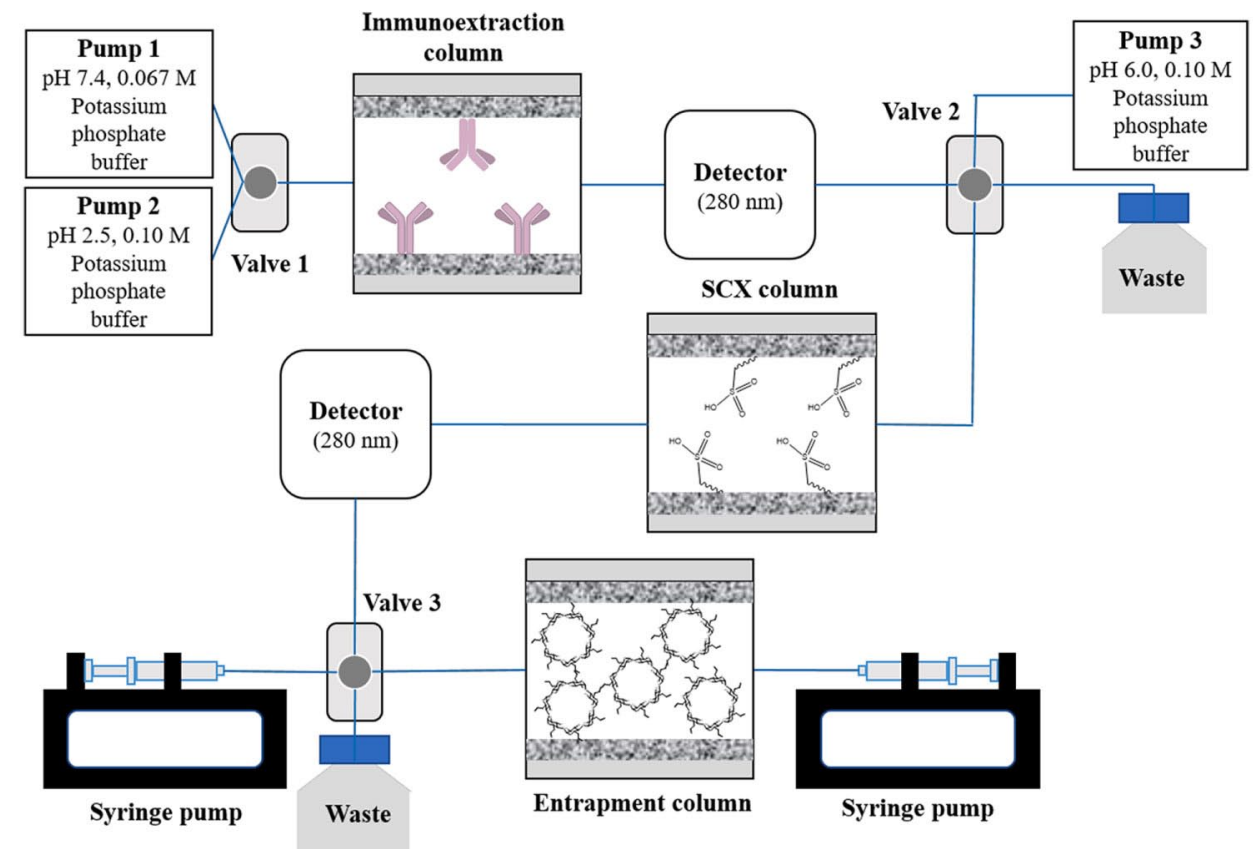

Fig. 2. General design of the on-line immunoextraction/ entrapment system. The injection buffer used for the immunoextraction column was $\mathrm{pH} 7.4$, 0.067 M potassium phosphate buffer, and the elution buffer was $\mathrm{pH} 2.5$, $0.10 \mathrm{M}$ potassium phosphate buffer. For the strong cation exchange (SCX) column, the elution buffer was pH 6.o, o.10 M potassium phosphate buffer. The elution of HSA from each column was monitored at $280 \mathrm{~nm}$. The isolated HSA was passed through a $1.0 \mathrm{~cm} \times 2.1 \mathrm{~mm}$ I.D. hydrazide-activated silica column at $\mathrm{pH} 6.0$ and entrapped in the presence of oxidized glycogen.

Sepharose 4B fast flow (recombinant protein expressed in E. coli), immunoglobulin G (IgG; goat, $\geq 95 \%$ pure), HSA (essentially fatty acid free, $\geq 96 \%$ ), glycogen (from bovine liver, $\geq 85 \%$ glucose), oxalic dihydrazide ( $>99 \%)$, acetohexamide (99\%), glibenclamide ( $\geq 99 \%)$, and racemic warfarin ( $\geq 98 \%$ ) were purchased from Sigma-Aldrich (St. Louis, MO, USA). The Nucleosil Si-300 and Si- 1000 silica $(7 \mu \mathrm{m}$, particle diameter; pore size, 300 or $1000 \mathrm{~A}$, respectively) were acquired from Macherey-Nagel (Duren, Germany). All buffers and aqueous solutions were prepared using water from a Milli-Q Advantage 10 A Water system and were filtered using $0.2 \mu \mathrm{m}$ nylon membranes (EMD Millipore, Billerica, MA, USA). 


\subsection{Instrumentation}

The immunoextraction/entrapment system was developed using a Jasco 2000 series HPLC system (Tokyo, Japan) and two Harvard apparatus PHD Ultra syringe pumps (Hilston, MA, USA). The components of the Jasco system were as follows: three PU-2080 pumps, an AS-2057 autosampler, a DG-2080-53 degasser, a CO-2067 column oven, a LV-2080-03 solvent selector and two UV-2075 Plus absorbance detectors. This HPLC system also employed three Rheodyne Advantage PF six-port valves (Cotati, CA, USA), which were used to alternate the flow and application of buffers to the columns of this system (see Supplemental Material). The HPLC/syringe pump system was operated using LC-Net and ChromNav V 1.18 software from Jasco. Chromatograms were analyzed by using PeakFit 4.12 software from Jandel Scientific (San Rafael, CA, USA) and Microsoft Excel 2016 (Redmond, WA, USA). Ultrafiltration and buffer exchange were carried out by using VivaSpin 6 ultrafiltration spin columns (30 $\mathrm{kDa}$ ) from Sartorious Stedim (Gottingen, Germany) and a 5702RH temperature-controlled centrifuge (Eppendorf, New York, NY, USA). The centrifuge was operated at $3000 \mathrm{rpm}$ and $25^{\circ} \mathrm{C}$ in most cases except during the purification of oxidized glycogen, when the temperature was $37^{\circ} \mathrm{C}$.

\subsection{Development of immunoextraction columns}

The anti-HSA immunoextraction columns were prepared by using affinity-purified polyclonal anti-HSA antibodies or anti-HSA goat serum. The affinity-purified anti-HSA antibodies were immobilized onto Nucleosil-1000 silica via the Schiff base method, as previously described [17]. A control support was developed in the same manner but in the absence of antibodies. Prior to immobilization, the buffer in which the anti-HSA antibodies were supplied was exchanged by ultrafiltration, with the antibodies being placed into $\mathrm{pH}$ 6.0, 0.10 M potassium phosphate buffer. The protein content of the anti-HSA support was determined in triplicate by utilizing a micro bicinchoninic acid (BCA) protein assay kit obtained from Thermo Fisher Scientific (Waltham, MA, USA). In this assay, goat IgG was used as the standard and the control support was employed as the blank. 
Isolation of polyclonal anti-HSA antibodies from anti-HSA goat serum was performed by using HSA silica [17] or protein G Sepharose [18]. A $200 \mathrm{mg}$ portion of lyophilized anti-HSA goat serum was dissolved in $2.0 \mathrm{~mL}$ of $\mathrm{pH} 7.4,0.067 \mathrm{M}$ potassium phosphate buffer and added to $4 \mathrm{mg}$ of protein $\mathrm{G}$ Sepharose or $0.50 \mathrm{~g}$ of HSA silica, with the latter being prepared using Nucleosil Si-100o silica and the Schiff base method [17]. The serum and support slurry were allowed to mix at room temperature for $2 \mathrm{~h}$. The slurry was centrifuged at $7500 \mathrm{rpm}$ for $3 \mathrm{~min}$ and room temperature to separate the retained anti-HSA antibodies from other serum components. The supernatant was decanted, and the support washed with $2.0 \mathrm{~mL}$ of the $\mathrm{pH} 7.4$ buffer prior to another centrifugation and decanting step. This step was repeated a total of three times. The retained anti-HSA antibodies were eluted from the protein G Sepharose or HSA silica by washing the support with three 1.0 $\mathrm{mL}$ portions of $\mathrm{pH} 2.5$, $0.10 \mathrm{M}$ potassium phosphate buffer, followed by a centrifugation step and recollection of the supernatant after each step. The $\mathrm{pH}$ of the collected anti-HSA antibodies was adjusted to $\mathrm{pH}$ 6.o by adding $\mathrm{pH}$ 8.0, o.10 M potassium phosphate buffer. These antibodies were immobilized onto 1.0 g of Nucleosil 1000-7 by the Schiff base method [17]. A control support was prepared in the same fashion but without any antibodies being included in the reaction mixture. The protein content of the anti-HSA support was measured by using a BCA assay, as described earlier.

The support made with the affinity-purified anti-HSA antibodies was packed into $1.0 \mathrm{~cm} \times 2.1 \mathrm{~mm}$ I.D. stainless steel columns at 4000 psi (27.6 MPa), with $\mathrm{pH} 7.4$, $0.067 \mathrm{M}$ potassium phosphate buffer being used as the packing solution. The anti-HSA support made from anti-HSA goat serum was packed in the same manner into $2.0 \mathrm{~cm}$ and $5.0 \mathrm{~cm} \times 2.1 \mathrm{~mm}$ I.D. columns (combined effective length, $7.0 \mathrm{~cm}$ ) . Control columns of the same sizes were also prepared in this manner. The columns were stored in $\mathrm{pH} 7.4$, 0.067 M potassium phosphate buffer at $4.0^{\circ} \mathrm{C}$. The binding capacity of each anti-HSA column was measured in triplicate by frontal analysis at $0.10 \mathrm{~mL} / \mathrm{min}$ and by using a $5.0 \mu \mathrm{M}$ solution of HSA in $\mathrm{pH} 7.4$, 0.067 M potassium phosphate buffer at $37{ }^{\circ} \mathrm{C}$. In this measurement, the active antibody content was determined by utilizing the difference in the midpoints of the breakthrough curves that were obtained on the anti-HSA column and a control column [18]. 


\subsection{Preparation of hydrazide-activated silica and oxidized glycogen}

Hydrazide-activated silica was prepared by using Nucleosil-30o silica as the starting material, which was first converted into a diolbonded form $[8,19]$. The diol-bonded silica was oxidized into an aldehyde form by using periodic acid, and hydrazide groups were incorporated by combining the aldehyde-activated silica with oxalic dihydrazide, as described previously $[8,9]$. Any remaining aldehyde groups on the support were reduced by using sodium borohydride $[8,19]$. The hydrazide-activated silica was stored at $4{ }^{\circ} \mathrm{C}$ in $\mathrm{pH}$ 7.0, $0.10 \mathrm{M}$ phosphate buffer, conditions under which this support is stable for up to 6 weeks [19]. This support was packed into $1.0 \mathrm{~cm} \times 2.1 \mathrm{~mm}$ I.D columns in the same manner as described in Section 2.3 for the anti- HSA supports. These columns were used within $24 \mathrm{~h}$ of being packed to minimize any loss of hydrazide groups on the support prior to entrapment.

Oxidation of glycogen was carried out by reacting $17 \mathrm{mg}$ of bovine glycogen with $135 \mathrm{mg}$ of periodic acid in $4.0 \mathrm{~mL}$ of $\mathrm{pH} 5.0,20 \mathrm{mM}$ acetate buffer containing $15 \mathrm{mM}$ sodium chloride [9]. The glycogen solution was vortexed for $5 \mathrm{~min}$, degassed for $5 \mathrm{~min}$, and placed on a wrist shaker (set at 300 oscillations per min) for $16 \mathrm{~h}$ at room temperature. The oxidized glycogen was purified by ultrafiltration, in which the oxidized glycogen solution was washed three times with water and three more times with $\mathrm{pH}$ 6.0, o.10 M potassium phosphate buffer. Each wash was followed by a centrifugation step that was performed at $3000 \mathrm{rpm}$ and $37^{\circ} \mathrm{C}$. The oxidized glycogen solution was removed from the ultrafiltration device with $4.0 \mathrm{~mL}$ of $\mathrm{pH}$ 6.0, 0.10 $\mathrm{M}$ potassium phosphate buffer and used immediately in the entrapment of HSA.

\subsection{Construction of immunoextraction/entrapment system}

The final immunoextraction/entrapment system used an effective anti-HSA column size of $8.0 \mathrm{~cm} \times 2.1 \mathrm{~mm}$ I.D. (i.e., one $1.0 \mathrm{~cm}$ long column based on affinity-purified anti-HSA antibodies, plus $2.0 \mathrm{~cm}$ and $5.0 \mathrm{~cm} \times 2.1$ I.D. columns using anti-HSA antibodies from goat serum), along with a $1.0 \mathrm{~cm} \times 2.1 \mathrm{~mm}$ I.D. strong cation exchange (SCX) Biobasic guard column (Sigma-Aldrich, St. Louis, MO, USA). The SCX column was used to recapture HSA that was retained and eluted from 
the immunoextraction columns and to place this protein into a buffer that could be used for entrapment. The elution of HSA during the development and utilization of this system was monitored at $280 \mathrm{~nm}$.

In this final system, the anti-HSA immunoextraction columns were first equilibrated with $\mathrm{pH} 7.4,0.067 \mathrm{M}$ potassium phosphate buffer at $0.10 \mathrm{~mL} / \mathrm{min}$. The SCX column was equilibrated with $\mathrm{pH} \mathrm{2.5,0.10}$ $\mathrm{M}$ potassium phosphate buffer at $0.50 \mathrm{~mL} / \mathrm{min}$. All of these columns were kept at $37{ }^{\circ} \mathrm{C}$. A $20.0 \mu \mathrm{L}$ sample containing HSA was injected at $0.10 \mathrm{~mL} / \mathrm{min}$ onto the immunoextraction columns in the presence of $\mathrm{pH} 7.4$, 0.067 M potassium phosphate buffer. After $10 \mathrm{~min}$, the retained HSA was eluted at $0.10 \mathrm{~mL} / \mathrm{min}$ by applying $\mathrm{pH} 2.5,0.10 \mathrm{M}$ potassium phosphate buffer. This elution was carried out for $25 \mathrm{~min}$ and was done with the immunoextraction columns connected on-line with the SCX column. The HSA that was captured by the SCX column was later eluted by using $\mathrm{pH}$ 6.0, o.10 M potassium phosphate buffer at $0.50 \mathrm{~mL} / \mathrm{min}$. The HSA that was eluted from the SCX column was collected over a period of $55 \mathrm{~s}$ in an on-line $500 \mu \mathrm{L}$ loop.

The HSA collected in the loop was next entrapped within a 1.0 $\mathrm{cm} \times 2.1 \mathrm{~mm}$ I.D. column that contained hydrazide-activated silica. This step was done by first passing the captured protein repeatedly through the column for $4 \mathrm{~h}$ at $20 \mu \mathrm{L} / \mathrm{min}$ by using two syringe pumps that were synchronized to withdraw and infuse the protein solution through the column $[9,12]$. The HSA solution was then combined manually with an equal volume of a solution containing $4.25 \mathrm{mg} / \mathrm{mL}$ of oxidized glycogen; this mixture was circulated through the column for another 16-20 h. In the final step, $450 \mu \mathrm{L}$ of $\mathrm{pH} 6.0,0.10 \mathrm{M}$ potassium phosphate buffer containing $1.0 \mathrm{mg} / \mathrm{mL}$ oxalic dihydrazide was applied for $2 \mathrm{~h}$ to the column to cap any remaining active aldehyde groups on the oxidized glycogen. A control column was made the same way but with $\mathrm{pH}$ 6.0, 0.10 M phosphate buffer being used in place of the HSA solution. The columns were then washed with $30.0 \mathrm{~mL}$ of $\mathrm{pH}$ 7.4 , $0.067 \mathrm{M}$ potassium phosphate buffer at $0.50 \mathrm{~mL} / \mathrm{min}$ and stored in the same buffer at $4{ }^{\circ} \mathrm{C}$.

\subsection{Chromatographic studies}

All injections onto the entrapped protein columns were made in triplicate at 0.25 or $0.50 \mathrm{~mL} / \mathrm{min}$ and $37^{\circ} \mathrm{C}$ in the presence of $\mathrm{pH} 7.4$, $0.067 \mathrm{M}$ potassium phosphate buffer as the mobile phase. The injected 
volume of the probe or drug solutions was $20 \mu \mathrm{L}$. A sample concentration of $10.0 \mu \mathrm{M}$ for warfarin or L-tryptophan was used during optimization of the entrapment conditions in Section 3.4; a warfarin concentration of $1.0 \mu \mathrm{M}$ was used in Sections 3.5 and 3.6. The void volume was measured by injecting 5.0 $\mu \mathrm{M}$ sodium nitrate, which is a non-retained solute for the types of columns and supports that were used in this study [20]. All sulfonylurea drugs were injected at a sample concentration of 1.0 $\mu \mathrm{M}$ except for glibenclamide, for which the sample concentration was 5.0 $\mu \mathrm{M}$ (Note: this was done to allow for good detection of the broad and strongly-retained peak for glibenclamide). The following wavelengths were used for detection: acetohexamide, $252 \mathrm{~nm}$; glibenclamide, $290 \mathrm{~nm}$; tolbutamide or glipizide, $226 \mathrm{~nm}$; sodium nitrate, $205 \mathrm{~nm}$; L-tryptophan, $280 \mathrm{~nm}$; and warfarin, $308 \mathrm{~nm}$. Serum was filtered prior to injection by using an Acrodisc PVDF syringe filter ( $0.2 \mu \mathrm{m}$ pore size) from Waters (Milford, MA, USA).

\section{Results and discussion}

\subsection{Characterization of immunoextraction columns}

The total antibody content for each immunoextraction support was measured by using a protein assay. The protein content when using the affinity-purified anti-HSA antibodies was $22.1( \pm 1.2) \mathrm{mg}$ antibodies/g silica, and the protein content when using anti-HSA antibodies from goat serum was 18.0 ( \pm 0.1$) \mathrm{mg}$ antibodies/g silica when using HSA silica for purification or $30.5( \pm 1.4) \mathrm{mg}$ antibodies/g silica when using protein $\mathrm{G}$. The support made with the affinity-purified anti-HSA antibodies was packed into a $1.0 \mathrm{~cm} \times 2.1 \mathrm{~mm}$ I.D. column, while the support made using the anti-HSA antibodies from goat serum was packed into $2.0 \mathrm{~cm}$ and $5.0 \mathrm{~cm} \times 2.1 \mathrm{~mm}$ I.D. columns (combined length, 7.0 $\mathrm{cm}$; using HSA silica and protein $\mathrm{G}$ for antibody purification, respectively). The total antibody content of these columns, based on a molar mass for the antibodies of $150 \mathrm{kDa}$ and a known packing density for the supports of $0.45 \mathrm{~g} / \mathrm{cm}^{3}$, was $2.30( \pm 0.12) \mathrm{nmol}$ or $35.2( \pm 1.2)$ nmol, respectively.

The binding capacity of each column was determined by using frontal analysis and solutions with known concentrations of HSA that were applied at $0.10 \mathrm{~mL} / \mathrm{min}, \mathrm{pH} 7.4$ and $37^{\circ} \mathrm{C}$. The binding capacity for 
the $1.0 \mathrm{~cm} \times 2.1 \mathrm{~mm}$ column was $0.27( \pm 0.02)$ nmol HSA, while the binding capacities for the $2.0 \mathrm{~cm}$ and $5.0 \mathrm{~cm} \times 2.1 \mathrm{~mm}$ columns were 1.38 ( \pm 0.05$)$ nmol HSA and $1.50( \pm 0.05)$ nmol HSA, respectively. By combining the data from the protein assays and frontal analysis, it was determined that $11.9( \pm 1.1) \%, 36.9( \pm 0.1) \%$ and $9.5( \pm 0.1) \%$ of the immobilized antibodies were active and able to bind HSA within the $1.0 \mathrm{~cm}, 2.0 \mathrm{~cm}$, and $5.0 \mathrm{~cm}$ long immunoextraction columns, respectively. The $1.0 \mathrm{~cm} \times 2.1 \mathrm{~mm}$ column containing affinity- purified anti-HSA antibodies was used in most of the following studies but was combined with the $2.0 \mathrm{~cm}$ and $5.0 \times 2.1 \mathrm{~mm}$ anti-HSA columns to increase the overall binding capacity in the final immunoextraction/ entrapment system (see Sections 2.5 and 3.5).

\subsection{Optimization of conditions for immunoextraction}

A $1.0 \mathrm{~cm} \times 2.1 \mathrm{~mm}$ I.D. immunoextraction column was used to study the capture efficiency of HSA while varying the injection flow rate. This was done by injecting $20 \mu \mathrm{L}$ of $10.0 \mu \mathrm{M}$ HSA in $\mathrm{pH} 7.4,0.067 \mathrm{M}$ potassium phosphate buffer onto the column at $37^{\circ} \mathrm{C}$. The retained HSA was eluted at $37{ }^{\circ} \mathrm{C}$ using $\mathrm{pH} 2.5$, o.10 M potassium phosphate buffer. Elution was performed at $\mathrm{pH} 2.5$ because this $\mathrm{pH}$ is known to effectively dissociate HSA from polyclonal antibodies without irreversibly affecting the structure of this protein or the antibodies [21-23]. This elution buffer was also chosen because it could act as a weak mobile phase for an SCX column, thus allowing use of this latter column for the retention and re-concentration of HSA that was eluted from the immunoextraction column (see Section 3.3).

In these experiments, the HSA was injected at flow rates ranging from 0.10 to $0.50 \mathrm{~mL} / \mathrm{min}$ into the $\mathrm{pH} 7.4$ application buffer of the immunoextraction column. After $10 \mathrm{~min}$, the retained HSA was eluted at $\mathrm{pH} 2.5$ and $0.10 \mathrm{~mL} / \mathrm{min}$, and the area of the eluted peak was measured. Injections using the same volume and concentration of HSA, but now in the presence of $\mathrm{pH} 2.5,0.10 \mathrm{M}$ phosphate buffer as the sample buffer and mobile phase, were made onto an inert control column to provide the total expected peak area.

The results are summarized in Table 1. Almost 94\% of the applied HSA was captured by a $1.0 \mathrm{~cm} \times 2.1 \mathrm{~mm}$ I.D. immunoextraction column at $0.10 \mathrm{~mL} / \mathrm{min}$. The protein sample in this experiment contained 0.20 nmol HSA, which represented $74 \%$ of the measured 
Table 1 Degree of capture and rate of elution of retained HSA at various flow rates when using a $1.0 \mathrm{~cm} \times 2.1 \mathrm{~mm}$ I.D. anti-HSA immunoextraction column. ${ }^{\mathrm{a}}$

\begin{tabular}{lll}
$\begin{array}{l}\text { Flow rate } \\
(\mathrm{mL} / \mathrm{min})\end{array}$ & Retained HAS & $\begin{array}{l}\text { Dissociation rate constant } \\
\text { at } \mathrm{pH} 2.5\left(\times 1 \mathrm{O}^{-3} \mathrm{~s}^{-1}\right)\end{array}$ \\
\hline 0.10 & $93.8( \pm 1.4) \%$ & $3.8( \pm 0.1)$ \\
0.25 & $86.5( \pm 1.0) \%$ & $4.4( \pm 0.1)$ \\
0.50 & $87.2( \pm 1.0) \%$ & $5.9( \pm 0.2)$ \\
\hline
\end{tabular}

a. The values in parentheses represent a range of \pm 1 S.D. $(n=3)$. The dissociation rate constants were obtained by fitting the natural logarithm of the elution peak at $\mathrm{pH} 2.5$ and the given flow rate to Eq. (1), as described in the text.

column binding capacity. For the same amount of sample, there was a small decrease of $6.6-7.3 \%$ (i.e., a difference significant at the $95 \%$ confidence level) when going from 0.10 to $0.25-0.50 \mathrm{~mL} / \mathrm{min}$. Thus, an application flow rate of $0.10 \mathrm{~mL} / \mathrm{min}$ was used in all further work with the immunoextraction columns. Similar or higher capture efficiencies would be expected for smaller amounts of applied HSA or columns with a higher binding capacity, such as the $2.0 \mathrm{~cm}$ plus 5.0 $\mathrm{cm} \times 2.1 \mathrm{~mm}$ immunoextraction columns that were used later in Sections 3.5-3.6 as part of the final immunoextraction/entrapment system $[21,22]$.

The backpressure and stability of the immunoextraction columns were also considered, as well as their ability to release the captured HSA. For a $1.0 \mathrm{~cm} \times 2.1 \mathrm{~mm}$ I.D. immunoextraction column, the backpressure increased from $0.3 \mathrm{MPa}(44 \mathrm{psi}$ ) at $0.10 \mathrm{~mL} / \mathrm{min}$ to $1.1 \mathrm{MPa}$ (16o psi) at $0.50 \mathrm{~mL} / \mathrm{min}$. A larger proportional change was noted for $2.0 \mathrm{~cm}$ plus $5.0 \mathrm{~cm} \times 2.1 \mathrm{~mm}$ I.D. immunoextraction columns, which gave an increase in backpressure of $1.7 \mathrm{MPa}(247 \mathrm{psi})$ at $0.10 \mathrm{~mL} / \mathrm{min}$ to $3.6 \mathrm{MPa}$ (522 psi) at $0.25 \mathrm{~mL} / \mathrm{min}$.

The stability of the combined immunoextraction columns and their release of captured HSA were monitored by comparing the peak area of the retained HSA after each injection for a standard sample of this protein (i.e., $20 \mu \mathrm{L}$ of $10.0 \mu \mathrm{M} \mathrm{HSA}$ ). After 48 injections there was a decrease of only $10 \%$ in the retained peak area (or $\sim 0.2 \%$ per application of HSA). This small decrease may have been due to a slow loss of activity in the anti-HSA antibodies over time, or a small level of carryover of non-eluted HSA. The gradual loss of column binding capacity was not a major issue in this study because the retained peak 
area was used to monitor and correct for the amount of HSA that was passed onto the rest of the system for capture by SCX or for use in entrapment.

The time needed to elute the captured HSA from an immunoextraction column at $\mathrm{pH} 2.5$ was next studied. This was done by using a $20 \mu \mathrm{L}$ sample of $630 \mu \mathrm{M}$ HSA (i.e., $42 \mathrm{~g} / \mathrm{L}$ HSA, a typical serum concentration of this protein; total injected HSA, $12.6 \mathrm{nmol}$ ) to saturate a set of coupled immunoextraction columns (i.e., the $1.0 \mathrm{~cm}$ and 2.0 $\mathrm{cm}$ plus $5.0 \mathrm{~cm} \times 2.1 \mathrm{~mm}$ I.D. columns) with a combined binding capacity for HSA of $3.15( \pm 0.07)$ nmol. The HSA sample was injected at $0.10 \mathrm{~mL} / \mathrm{min}$ and $37{ }^{\circ} \mathrm{C}$ in the presence of $\mathrm{pH} 7.4$, $0.067 \mathrm{M}$ potassium phosphate buffer, followed by a 10 min wash at $\mathrm{pH} 7.4$ and elution of the retained HSA at $0.10 \mathrm{~mL} / \mathrm{min}$ using $\mathrm{pH} 2.5,0.10 \mathrm{M}$ phosphate buffer. A similar study was carried out by applying $20 \mu \mathrm{L}$ of 10 $\mu \mathrm{M}$ HSA at $0.10 \mathrm{~mL} / \mathrm{min}$ to a $1.0 \mathrm{~cm} \times 2.1 \mathrm{~mm}$ I.D. anti-HSA column to examine the elution profile when an immunoextraction column was not fully saturated with HSA (i.e., conditions using $74 \%$ of the available binding capacity).

The profile of the eluting peak was examined by peak decay analysis [24-27]. This was done by employing Eq. (1) to determine the dissociation rate constant $\left(k_{d}\right)$ for HSA as it was released from an immunoextraction column [25].

$\ln \left(\frac{d m_{A e}}{d t}\right)=\ln \left(k_{d} m_{A o}\right)-k_{d} t$

In this equation, $m_{A O}$ represents the moles of HSA (or analyte, A) that were initially bound to the column, and $m_{A e}$ is the moles of A that eluted at time $t$. This equation indicates that a plot of the natural logarithm of the elution peak versus time for a process that follows pseudo-first order dissociation (i.e., as is often present during the elution of analytes from immobilized antibodies) should result in a linear response with a slope equal to $-k_{d}[25]$.

Fig. 3 shows some typical results that were obtained when Eq. (1) was fit to the elution profile for HSA when the combined $1.0 \mathrm{~cm}$ and $2.0 \mathrm{~cm}$ plus $5.0 \mathrm{~cm} \times 2.1 \mathrm{~mm}$ I.D. immunoextraction columns were saturated with this protein. A relatively broad elution peak was seen for HSA from these columns, as shown in Fig. 3(a) and has been noted for other systems based on immunoextraction [22,27]. The integrated 

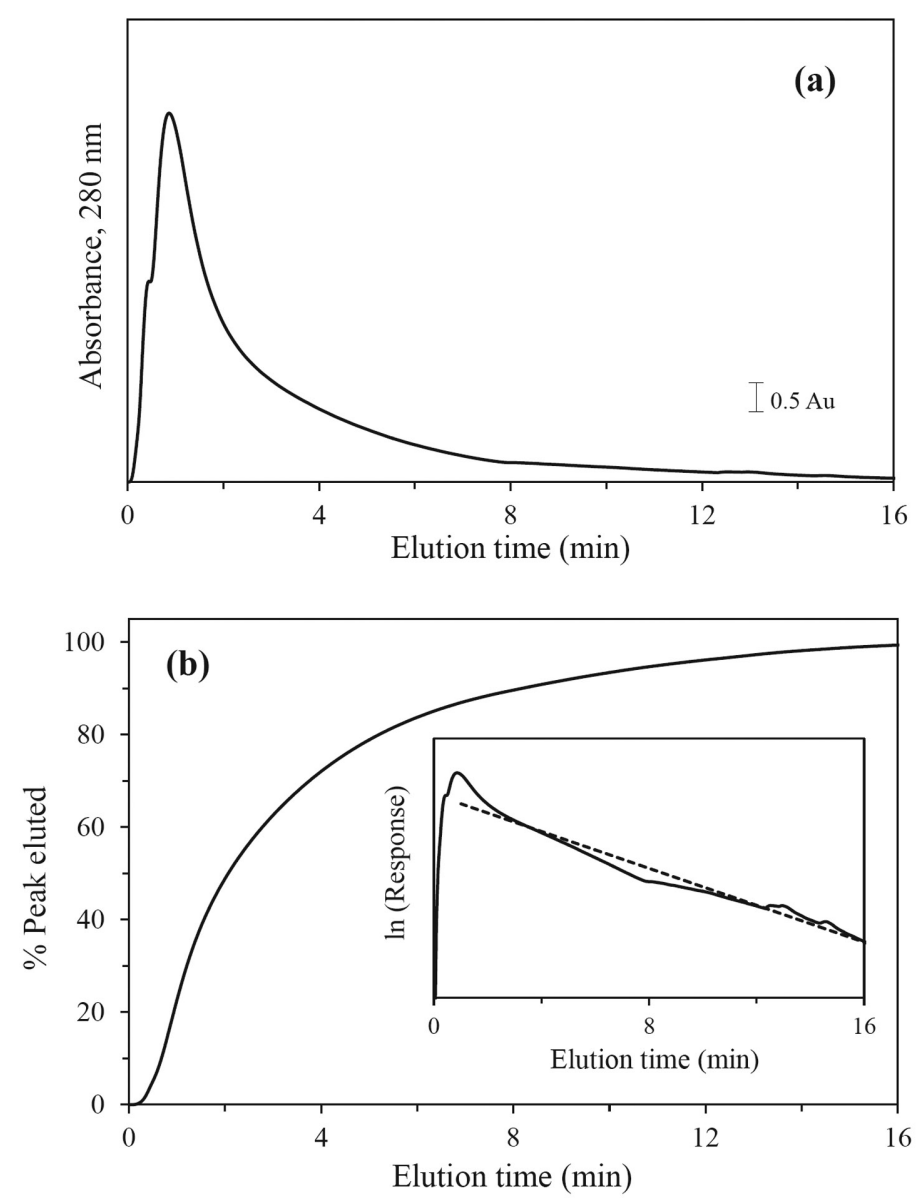

Fig. 3. (a) Elution of HSA from a set of immunoextraction columns $(1.0 \mathrm{~cm}$ and $2.0 \mathrm{~cm}$ plus $5.0 \times 2.1 \mathrm{~mm}$ I.D. anti-HSA columns connected in tandem) at $0.10 \mathrm{~mL} /$ min and $37^{\circ} \mathrm{C}$ in the presence of $\mathrm{pH} \mathrm{2.5,} \mathrm{0.10} \mathrm{M} \mathrm{phosphate} \mathrm{buffer} \mathrm{and} \mathrm{(b)} \mathrm{the} \mathrm{rel-}$ ative amount of HSA eluted versus time under these conditions. The time scale begins at the point at which the elution buffer was applied to the immunoextraction columns (i.e., 10 min after the initial injection of HSA). The chromatograms have been corrected for the background response obtained when no HSA was present. The inset in (b) shows the logarithmic transform of the elution peak and the linear region of this plot, as determined according to Eq. (1) and described by the best-fit line $y=-0.2494 \times+12.49$ (correlation coefficient, o.9814). Abbreviations: Au, absorbance units.

form of the peak, as shown in Fig. 3(b), indicated that $>99 \%$ of the HSA eluted in $15.2 \mathrm{~min}$ at $0.10 \mathrm{~mL} / \mathrm{min}$ and $>99.9 \%$ eluted in $18.0 \mathrm{~min}$. Based on these results, elution was allowed to occur for at least $18 \mathrm{~min}$ and up to $25 \mathrm{~min}$ in all later experiments in this study. The logarithmic transform of this peak profile gave a reasonably good fit with Eq. (1) and a first-order decay model at times of $1.7 \mathrm{~min}$ or greater at 0.10 
$\mathrm{mL} / \mathrm{min}$, as shown by the inset of Fig. 3. The slope for this fit gave an estimated dissociation rate constant between HSA and the anti-HSA antibodies of $4.2( \pm 0.1) \times 10^{-3} \mathrm{~s}^{-1}$ at $\mathrm{pH} 2.5$ and $37^{\circ} \mathrm{C}$. Similar dissociation rate constants of 3.8-4.4 $\times 10^{-3} \mathrm{~s}^{-1}$ were obtained over comparable elution times and at 0.10 or $0.25 \mathrm{~mL} / \mathrm{min}$ when a nonsaturating amount of HSA was applied to a $1.0 \mathrm{~cm} \times 2.1 \mathrm{~mm}$ I.D. immunoextraction column (see Table 1).

\subsection{Optimization of conditions for strong cation-exchange}

The flow rate and $\mathrm{pH}$ conditions to be used with a small SCX column to capture and elute HSA were next considered. In these experiments, $20 \mu \mathrm{L}$ of $2.5 \mu \mathrm{M}$ HSA (or $0.05 \mathrm{nmol}$ ) in $\mathrm{pH} \mathrm{2.5}$, $0.10 \mathrm{M}$ potassium phosphate buffer was injected onto a $1.0 \mathrm{~cm} \times 2.1 \mathrm{~mm}$ I.D. SCX column. These injections were made in the presence of $\mathrm{pH} 2.5$, o.10 $\mathrm{M}$ potassium phosphate buffer at $0.10 \mathrm{~mL} / \mathrm{min}$ and $37^{\circ} \mathrm{C}$ (i.e., the same conditions selected in the previous section for eluting HSA from the immunoextraction columns). Under these injection and application conditions, an average of $95.5( \pm 1.4) \%$ HSA was retained by the SCX column.

The effect of altering the $\mathrm{pH}$ of the SCX elution buffer was next considered. The isoelectric point ( $\mathrm{pI}$ ) of HSA is 4.7. This means the overall charge of HSA at a pH higher than 4.7 will be negative [1,21], with elution of this protein becoming easier from a negativelycharged SCX column as the $\mathrm{pH}$ is increased to 5.0 or higher. In addition to the $\mathrm{pH}$ of 5.0 that was initially employed, elution buffers with a pH of 6.0 or 7.0 were also examined. This work was done at an elution flow rate of $0.25 \mathrm{~mL} / \mathrm{min}$ and $37^{\circ} \mathrm{C}$. As shown in Fig. 4(a), pH 5.0 gave the broadest elution profile for HSA from the SCX column, with narrower elution profiles being obtained at $\mathrm{pH} 6.0$ and 7.0. For instance, increasing the mobile phase $\mathrm{pH}$ from 5.0 to 6.0 or 7.0 at $0.25 \mathrm{~mL} / \mathrm{min}$ resulted in 2.0- to 2.5-faster elution of HSA from the SCX column. An elution $\mathrm{pH}$ of 6.0 was selected for later use in this report due to its ability to quickly elute HSA from the SCX column and its compatibility with the conditions that were needed for entrapment, as discussed in Section 3.4.

The elution flow rates and times that could be used to remove and collect HSA from the SCX column were examined. The backpressure of the SCX column at $\mathrm{pH}$ 6.0 ranged from only $0.4 \mathrm{MPa}$ (58 psi) at 0.10 

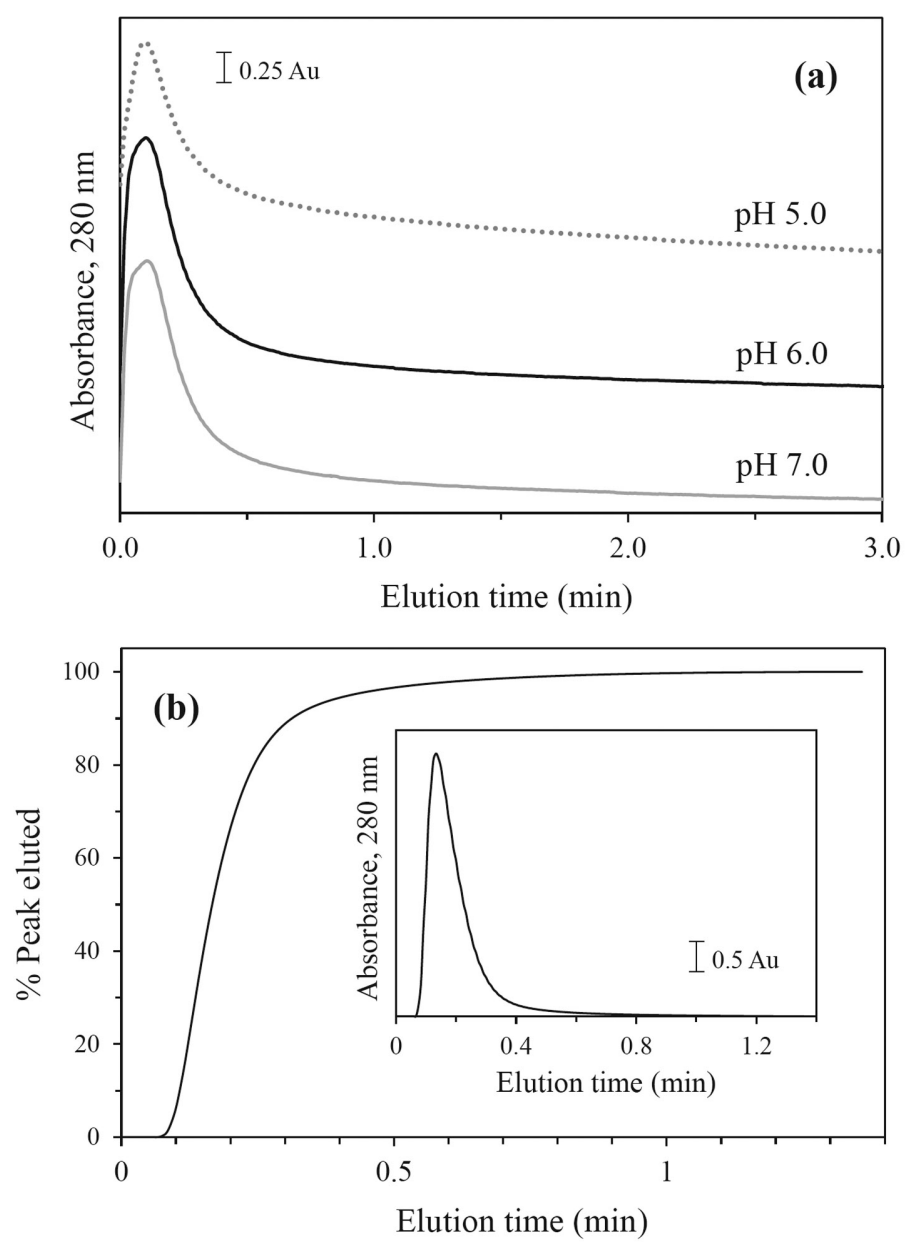

Fig. 4. (a) Elution of HSA from a $1.0 \mathrm{~cm} \times 2.1 \mathrm{~mm}$ I.D. SCX column at $0.25 \mathrm{~mL} / \mathrm{min}$ and at $\mathrm{pH} 5.0,6.0$ or 7.0 and (b) the relative amount of HSA eluted versus time from the SCX column at $\mathrm{pH} 6.0$ and $0.50 \mathrm{~mL} / \mathrm{min}$, where the inset shows the original elution profile. The time scale begins at the point at which the elution buffer was applied to the SCX column (i.e., 35 min after injection of HSA onto the immunoextraction columns). The chromatograms have been corrected for the background response obtained when no HSA was present. Abbreviations: Au, absorbance units.

$\mathrm{mL} / \mathrm{min}$ to $1.3 \mathrm{MPa}(188 \mathrm{psi}$ ) at $0.50 \mathrm{~mL} / \mathrm{min}$. All of these backpressures were acceptable for use in this report. Fig. 4(b) shows the elution profile of HSA from the SCX column that was obtained at 0.50 $\mathrm{mL} / \mathrm{min}$ and $\mathrm{pH}$ 6.o, following application of a $20 \mu \mathrm{L}$ solution containing $42 \mathrm{~g} / \mathrm{L}$ HSA onto the immunoextraction columns, and capture of the retained HSA by the SCX column, as described in the previous section. The resulting elution peak was similar in shape to those shown in Fig. 4(a) at $0.25 \mathrm{~mL} / \mathrm{min}$, but with the peak maximum at $0.50 \mathrm{~mL} /$ 
min appearing at a proportionately shorter time. As shown in Fig. 4(b), $95 \%$ of this peak eluted within $25 \mathrm{~s}$ at $0.50 \mathrm{~mL} / \mathrm{min}$ and $99 \%$ eluted within $46 \mathrm{~s}$ (i.e., elution volumes of $\sim 208$ and $380 \mu \mathrm{L}$, respectively). As this peak eluted, it was collected by passing the SCX column eluent through an on-line $500 \mu \mathrm{L}$ loop. This collection occurred over the first min of elution from the SCX column, or between 35 and 36 min after the original injection of the HSA sample onto the immunoextraction column (i.e., a time over which $>99.7 \%$ of the HSA was eluted). Based on this information and the results in Fig. 4, an elution $\mathrm{pH}$ of 6.0 and flow rate of $0.50 \mathrm{~mL} / \mathrm{min}$ for the SCX column were used in all further studies in this report.

\subsection{Optimization of conditions for entrapment}

Protein entrapment by the method shown in Fig. 1 is normally performed at $\mathrm{pH}$ 5.O to allow hydrazide groups on the support to react with oxidized glycogen and entrap a protein such as HSA [8-12]. However, other $\mathrm{pH}$ values that are above or below 5.0 may also be used for this process [19]. In the previous section it was determined that $\mathrm{pH}$ 6.0, 0.10 M phosphate buffer was effective in releasing HSA from the SCX column. Because this $\mathrm{pH}$ was higher than the value of 5.0 that is often used for entrapment [8-12], the effect of using $\mathrm{pH}$ 6.o for the entrapment of HSA was next examined. A $300 \mu \mathrm{L}$ portion of a solution containing $100 \mathrm{mg} / \mathrm{mL}$ HSA in $\mathrm{pH}$ 6.0, o.10 M phosphate buffer was first infused and withdrawn through a $1.0 \mathrm{~cm} \times 2.1 \mathrm{~mm}$ I.D. column containing hydrazide-activated silica, according to conditions given in Section 2.5 and used previously at $\mathrm{pH}$ 5.0 [9]. This was followed by the infusion and withdrawal of an equal volume mixture of $4.25 \mathrm{mg} / \mathrm{mL}$ oxidized glycogen and $100 \mathrm{mg} / \mathrm{mL}$ HSA in $\mathrm{pH} 6.0$ buffer, o.10 M phosphate buffer, and then capping of any remaining aldehyde groups (i.e., as described in Section 2.5) [9]. For comparison, a column containing entrapped HSA was prepared in the same manner but using $\mathrm{pH}$ 5.0, $20 \mathrm{mM}$ acetate buffer containing $15 \mathrm{mM}$ sodium chloride. Control columns were also prepared at $\mathrm{pH} 6.0$ and $\mathrm{pH} 5.0$ with no HSA being applied during the entrapment process.

The protein content of each column was determined by means of zonal elution and using warfarin and L-tryptophan as probe compounds $[17,28]$. Warfarin is known to bind at Sudlow site I of HSA and L-tryptophan binds at Sudlow site II with association equilibrium 
constants of $2.4 \times 10^{5} \mathrm{M}^{-1}$ [17] and $1.1 \times 10^{4} \mathrm{M}^{-1}$ [28], respectively, at $\mathrm{pH} 7.4$ and $37^{\circ} \mathrm{C}$. The moles of active protein $\left(m_{L}\right)$ in each entrapped HSA column was estimated by using Eq. (2) and the measured retention factor $(k)$ for a given probe compound [29].

$k=\frac{K_{a} m_{L}}{V_{m}}$

In this equation, $K_{a}$ is the association equilibrium constant for the probe with HSA, and $V_{m}$ is the column void volume (i.e., as determined by injecting sodium nitrate as a non-retained solute). Based on this relationship, the HSA contents of the columns made at $\mathrm{pH} 5.0$ and 6.0 were determined to be $19.5( \pm 1.3) \mathrm{nmol}$ and $14.6( \pm 0.7) \mathrm{nmol}$, respectively. A decrease of about $25 \%$ in HSA content occurred when using $\mathrm{pH} 6.0$ instead of 5.0 for entrapment, a difference that was significant at the 95\% confidence level; however, these results did indicate that $\mathrm{pH}$ 6.o could still be effectively used for the entrapment process. Thus, $\mathrm{pH}$ 6.0 was used as both the elution $\mathrm{pH}$ for the SCX column and as the $\mathrm{pH}$ for the entrapment process in the remainder of this report.

\subsection{Preparation of HSA columns using immunoextraction/} entrapment system

The final immunoextraction/entrapment system, as based on the conditions selected in Sections 3.1-3.4, was first tested for use in preparing small columns for drug binding studies by using a sample that contained a commercial sample of purified HSA. This sample was prepared in $\mathrm{pH} 7.4$, 0.067 $\mathrm{M}$ phosphate buffer at a physiological concentration of HSA ( $42 \mathrm{~g} / \mathrm{L})$. A $20 \mu \mathrm{L}$ injection of this HSA solution was made onto the system, and the captured HSA was entrapped within a $1.0 \mathrm{~cm} \times 2.1 \mathrm{~mm}$ I.D. hydrazide-activated silica column in the presence of oxidized glycogen. A control column was prepared in a similar manner off-line and with no HSA being applied. The protein content of the entrapped HSA column was again determined by using Eq. (2) and injecting warfarin as a probe compound with known binding properties for HSA [17]. The protein content of the column was found in this manner to be $0.56( \pm 0.10)$ nmol HSA.

The entrapped HSA column was employed to measure the global affinity constants $\left(n K_{a}\right)$ [10-13] for HSA with several sulfonylurea 
drugs: acetohexamide, glibenclamide, glipizide and tolbutamide. These drugs have been used in the management of glucose levels in blood in diabetic patients and have global affinity constants for HSA that have been measured in prior studies [13-16]. All of these drugs were injected in triplicate at $0.25 \mathrm{~mL} / \mathrm{min}$ and $37^{\circ} \mathrm{C}$ using $\mathrm{pH} 7.4$, $0.067 \mathrm{M}$ phosphate buffer as the mobile phase (i.e., the same temperature, $\mathrm{pH}$ and buffer conditions as used in prior binding studies in Refs. [13-16]). The same drugs and conditions were used on a control column to detect and correct for any non-specific interactions of these drugs with the support. Fig. 5 shows some typical chromatograms that were obtained in these studies, with results being acquired for most of the drugs within 3.0 min of injection at $0.25 \mathrm{~mL} /$ min. The only exception was glibenclamide, which had the strongest binding and highest retention on the HSA column and which eluted within about $8 \mathrm{~min}$.
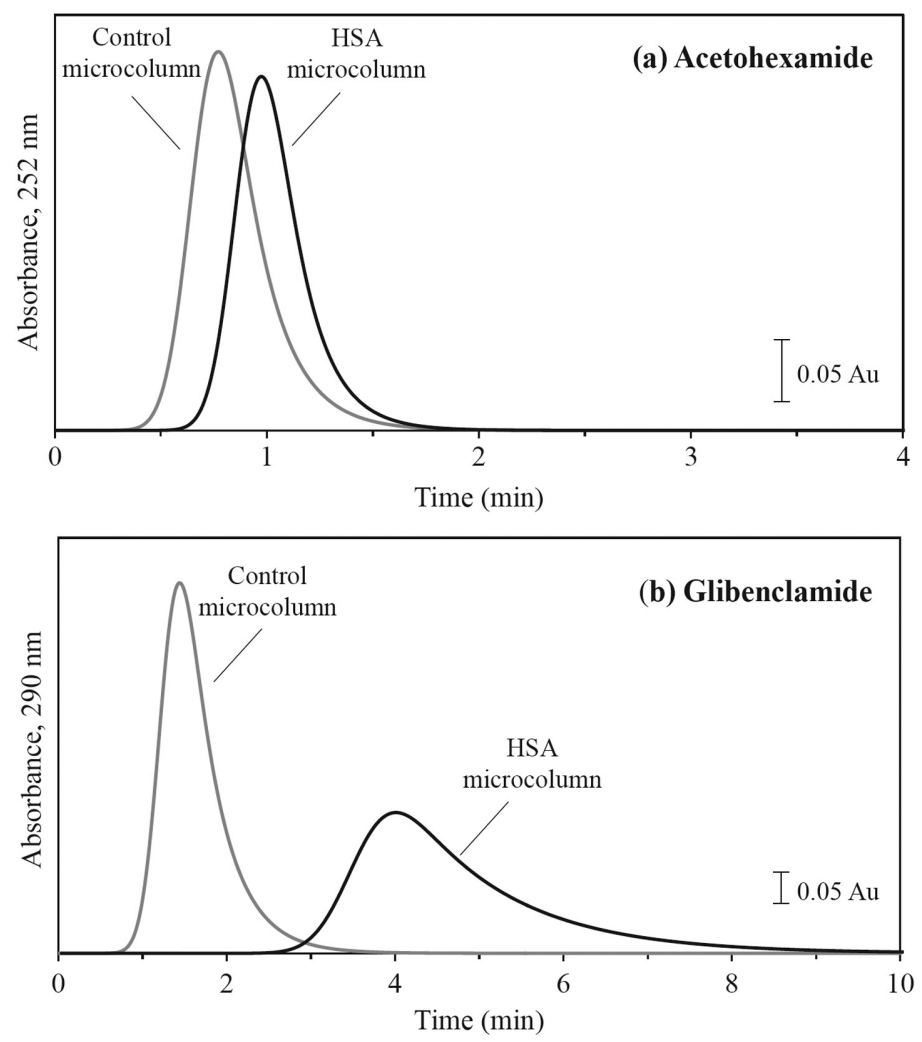

Fig. 5. Retention noted for samples of (a) $1.0 \mu \mathrm{M}$ acetohexamide or (b) $5.0 \mu \mathrm{M}$ glibenclamide that were injected onto a $1.0 \mathrm{~cm} \times 2.1 \mathrm{~mm}$ I.D. entrapped HSA column or control column in the presence of $\mathrm{pH} 7.4,0.067 \mathrm{M}$ potassium phosphate buffer at $0.25 \mathrm{~mL} / \mathrm{min}$ and $37^{\circ} \mathrm{C}$. Abbreviations: Au, absorbance units. 
Table 2 Retention factors measured for various sulfonylurea drugs on a $1.0 \mathrm{~cm} \times 2.1 \mathrm{~mm}$ I.D. entrapped HSA column and control column. ${ }^{\mathrm{a}}$

\begin{tabular}{llll} 
Drug & $\begin{array}{l}\text { Retention factor } \\
\text { on control column }\end{array}$ & $\begin{array}{l}\text { Retention factor } \\
\text { on HSA column }\end{array}$ & $\begin{array}{l}\text { Specific retention } \\
\text { factor due to HSA }\end{array}$ \\
\hline Acetohexamide & o.6o $( \pm 0.07)$ & $3.47( \pm 0.36)$ & $2.87( \pm 0.37)$ \\
Glibenclamide & $8.71( \pm 0.99)$ & $41.2( \pm 2.9)$ & $32.4( \pm 3.1)$ \\
Glipizide & $0.02( \pm 0.02)$ & $3.35( \pm 0.35)$ & $3.33( \pm 0.35)$ \\
Tolbutamide & $0.02( \pm 0.01)$ & $2.01( \pm 0.82)$ & $1.99( \pm 0.26)$ \\
\hline
\end{tabular}

a. The values in parentheses represent a range of \pm 1 S.D. $(n=3)$.

b. The specific retention factor due to HSA represents the difference between the retention factors that were measured for a drug in the presence of entrapped HSA and on the control column in the absence of any HSA. The values in parentheses for these results were determined by error propagation.

The retention factors measured for the sulfonylurea drugs on the HSA and control columns are summarized in Table 2. The specific retention factor for each drug due to HSA was obtained by subtracting the retention factor for the drug on the control column from that measured on the HSA column. The non-specific interactions of these drugs with the support, as determined by comparing their retention on the HSA and control columns, accounted for only 1-21\% (average, $10 \%$ ) of the total retention factors measured on the HSA column. The specific retention factors measured for these drugs had precisions of $\pm 9 \cdot 5-13 \%$ (average, $\pm 11 \%$ ).

The global affinity constants that were calculated from these results are shown in Table 3. The precision of these values ranged from \pm $16-18 \%$ (average, $\pm 17 \%$ ). The corresponding global affinity constants that were measured for the HSA that was applied in buffer spanned

Table 3 Global affinity constants obtained for representative sulfonylurea drugs using $1.0 \mathrm{~cm}$ $\times 2.1 \mathrm{~mm}$ I.D. columns containing entrapped HSA. ${ }^{\mathrm{a}}$

\begin{tabular}{llll} 
Drug & \multicolumn{2}{l}{ Global affinity constant $\left(\mathrm{M}^{-1}\right)^{\mathrm{a}}$} \\
\cline { 2 - 4 } & $\begin{array}{l}\text { Entrapment using } \\
\text { purified HSA }\end{array}$ & $\begin{array}{l}\text { Entrapment using } \\
\text { human serum }\end{array}$ & $\begin{array}{l}\text { Literature value } \\
{[\text { Ref.] }}\end{array}$ \\
\hline Acetohexamide & $1.75( \pm 0.31) \times 10^{5}$ & $1.67( \pm 0.22) \times 10^{5}$ & $1.7( \pm 0.1) \times 10^{5}[13]$ \\
Glibenclamide & $1.98( \pm 0.35) \times 10^{6}$ & $2.56( \pm 0.29) \times 10^{6}$ & $2.11( \pm 0.47) \times 10^{6}[14]$ \\
Glipizide & $2.03( \pm 0.33) \times 10^{5}$ & $2.27( \pm 0.22) \times 10^{5}$ & $2.57( \pm 0.80) \times 10^{5}[15]$ \\
Tolbutamide & $1.22( \pm 0.22) \times 10^{5}$ & $1.27( \pm 0.15) \times 10^{5}$ & $1.08( \pm 0.03) \times 10^{5}[16]$ \\
\hline
\end{tabular}

a. The values shown in parentheses represent a range of \pm 1 S.D. $(n=3)$. All global affinity constants were measured at $\mathrm{pH} 7.4$ and $37^{\circ} \mathrm{C}$. 
from 1.22 to $19.8 \times 10^{5} \mathrm{M}^{-1}$. These global affinities were consistent with those that have been previously reported for the same drugs with HSA under equivalent $\mathrm{pH}$ and temperature conditions [13-16]. These values were all equivalent to those from the literature at the $95 \%$ confidence level. The results indicated that the immunoextraction/entrapment system could be used to make HSA columns for binding studies and that these columns could be effectively used in the rapid determination of a drug's overall affinity for HSA.

\subsection{Preparation of entrapped HSA columns from serum}

The system was also used to entrap HSA from serum. This was performed by filtering the serum and mixing it $1: 1$ with $\mathrm{pH} 7.4,0.067 \mathrm{M}$ phosphate buffer. This mixture was then applied to the immunoextraction/ entrapment system and used to entrap the captured HSA in a $1.0 \mathrm{~cm} \times 2.1 \mathrm{~mm}$ I.D. column, as described in Section 3.5. It was determined by using Eq. (2) and injecting warfarin as a probe that 0.35 $( \pm 0.08)$ nmol of HSA from the diluted serum was entrapped by this method.

The global affinity constants for acetohexamide, glibenclamide, glipizide, and tolbutamide were again determined, but now using the entrapped HSA column that was prepared from serum. The results are included in Table 3. These results were again equivalent at the 95\% confidence level to those reported in the literature [13-16]. Similar agreement was seen with the values obtained in Section 3.5 when using an entrapped HSA column that was prepared from commercial, purified HSA. The precisions of the global affinities obtained when using entrapped HSA from serum were $\pm 9.7-13.6 \%$ (average, $\pm 11.6 \%$ ), which were similar to the precisions seen in Section 3.5 for columns made through the entrapment of purified HSA.

The stabilities of both the columns made from serum and purified HSA were also examined. No significant variations, at a 95\% confidence level, were observed in the retention times of drugs that were injected over the course of two weeks on either type of column. This level of stability was seen over at least 60 injections on a column containing purified HSA (as observed over several applications of fresh portions of HSA) and a similar value of over 54 injections on a column made from serum. The combined results indicated that the 
immunoextraction/entrapment system could be used to capture and isolate a protein like HSA from a solution or a sample such as serum and to place this protein into a column for use in HPAC and multiple drug binding studies.

\section{Conclusion}

In this study a system was developed that could purify, extract and entrap HSA within small affinity columns. The system utilized an immunoextraction column containing polyclonal anti-HSA antibodies that could extract HSA from either aqueous samples or serum. The immunoextraction column was used in tandem with a SCX column to concentrate the captured HSA and place it into a buffer that had a suitable $\mathrm{pH}$ for entrapment. The entrapment of HSA was performed on this system by using a hydrazide-activated column and oxidized glycogen as a capping agent. The $1.0 \mathrm{~cm} \times 2.1 \mathrm{~mm}$ I.D. HSA columns that were created by this system had a typical protein content of $0.3-0.6$ nmol. These columns were stable over several weeks and more than 50-6o sample injections when used in drug binding studies.

The HSA columns created by using this system were used to measure the global affinity constants for HSA with various sulfonylurea drugs. These binding constants could be determined in a matter of minutes, had precisions of around $\pm 10-18 \%$, and gave good agreement with literature values. A potential future application of this system is in the field of personalized medicine. For instance, small HSA columns could be developed by using individual serum samples to examine drug interactions with the entrapped protein to aid in patient treatment [30]. This would include work with both normal HSA and glycated forms of HSA, which have been shown to have equivalent binding to the types of polyclonal anti-HSA antibodies that were employed in this study [30]. Given the strong and selective binding of antibodies when used in affinity columns [31,32], the same type of system as used here for HSA could also be adapted in future work to capture and entrap other, lower-abundance proteins for binding studies or related applications by employing alternative antibodies against the given target for immunoextraction. 
Competing Interests - The authors declare that they have no known competing financial interests or personal relationships that could have appeared to influence the work reported in this paper.

Acknowledgments - This work was supported by the National Institutes of Health under grant Ro1 DKo69629.

Supplementary material - Supplementary data to this article (Figure S1) follows the References.

\section{References}

[1] T. Peters Jr, All about albumin, Academic Press, San Diego, CA, 1995.

[2] M. Fasano, S. Curry, E. Terreno, M. Galliano, G. Fanali, P. Narciso, S. Notari, P. Ascenzi, The extraordinary ligand binding properties of human serum albumin, IUBMB Life 57 (2005) 787-796.

[3] J. Ghuman, P.A. Zunszain, I. Petitpas, A.A. Bhattacharya, M. Otagiri, S. Curry, Structural basis of the drug-binding specificity of human serum albumin, J. Mol. Biol. 353 (2005) 38-52.

[4] U. Kragh-Hansen, V.T.G. Chuang, M. Otagiri, Practical aspects of the ligandbinding and enzymatic properties of human serum albumin, Biol. Pharm. Bull. 25 (2002) 695-704.

[5] M.D. Duong-Thi, E. Meiby, M. Bergstrom, T. Fex, R. Isaksson, S. Ohlson, Weak affinity chromatography as a new approach for fragment screening in drug discovery, Anal. Biochem. 414 (2011) 138-146.

[6] C. Zhang, E. Rodriguez, C. Bi, X. Zheng, D. Suresh, K. Suh, Z. Li, F. Elsebaei, D.S. Hage, High performance affinity chromatography and related separation methods for the analysis of biological and pharmaceutical agents, Analyst 143 (2018) 374-391.

[7] H. Seung Kim, D.S. Hage, Immobilization methods for affinity chromatography, in: D.S. Hage (Ed.), Handbook of Affinity Chromatography, second ed.,, Taylor \& Francis, BocaRaton, FL, 2005, pp. 36-68.

[8] A.J. Jackson, H. Xuan, D.S. Hage, Entrapment of proteins in glycogen-capped and hydrazide-activated supports, Anal. Biochem. 404 (2010) 106-108.

[9] J. Vargas-Badilla, S. Poddar, S. Azaria, C. Zhang, D.S. Hage, Optimization of protein entrapment in affinity microcolumns using hydrazide-activated silica and glycogen as a capping agent, J. Chromatogr. B 1121 (2019) 1-8.

[10] A.J. Jackson, J. Anguizola, E.L. Pfaunmiller, D.S. Hage, Use of entrapment and highperformance affinity chromatography to compare the binding of drugs and sitespecific probes with normal and glycated human serum albumin, Anal. Bioanal. Chem. 405 (2013) 5833-5841.

[11] C. Bi, A. Jackson, J. Vargas-Badilla, R. Li, G. Rada, J. Anguizola, E. Pfaunmiller, D.S. Hage, Entrapment of alpha1-acid glycoprotein in high-performance 
affinity columns for drug-protein binding studies, J. Chromatogr. B 1021

(2016) 188-196.

[12] J. Anguizola, C. Bi, M. Koke, A. Jackson, D.S. Hage, On-column entrapment of alpha1-acid glycoprotein for studies of drug-protein binding by highperformance affinity chromatography, Anal. Bioanal. Chem. 408 (2016) 5745-5756.

[13] R. Matsuda, J. Anguizola, K.S. Joseph, D.S. Hage, Analysis of drug interactions with modified proteins by high-performance affinity chromatography: binding of glibenclamide to normal and glycated human serum albumin, J. Chromatogr. A 1265 (2012) 114-122.

[14] X. Zheng, R. Matsuda, D.S. Hage, Analysis of free drug fractions by ultrafast affinity extraction: Interactions of sulfonylurea drugs with normal or glycated human serum albumin, J. Chromatogr. A 1371 (2014) 82-89.

[15] R. Matsuda, Z. Li, X. Zheng, D.S. Hage, Analysis of glipizide binding to normal and glycated human serum albumin by high-performance affinity chromatography, Anal. Bioanal. Chem. 407 (2015) 5309-5321.

[16] P. Tao, Z. Li, R. Matsuda, D.S. Hage, Chromatographic studies of chlorpropamide interactions with normal and glycated human serum albumin based on affinity microcolumns, J. Chromatogr. B 1098 (2018) 64-73.

[17] B. Loun, D.S. Hage, Chiral separation mechanisms in protein-based HPLC Columns. 1. Thermodynamic studies of (R)- and (S)-warfarin binding to immobilized human serum albumin, Anal. Chem. 66 (1994) 3814-3822.

[18] R. Matsuda, D. Jobe, J. Beyersdorf, D.S. Hage, Analysis of drug-protein binding using on-line immunoextraction and high-performance affinity microcolumns: studies with normal and glycated human serum albumin, J. Chromatogr. A. 1416 (2015) 112-120.

[19] P.F. Ruhn, S. Garver, D.S. Hage, Development of dihydrazide-activated silica supports for high-performance affinity chromatography, J. Chromatogr. A 669 (1994) 9-19.

[20] K.S. Joseph, D.S. Hage, Characterization of the binding of sulfonylurea drugs to HSA by high-performance affinity chromatography, J. Chromatogr. B 878 (2010) 1590-1598.

[21] I.M. Vlasova, A.M. Saletsky, Study of the denaturation of human serum albumin, J. Appl. Spectrosc. 76 (2009) 536-541.

[22] D.S. Hage, R.R. Walters, Dual-column determination of albumin and immunoglobulin $\mathrm{G}$ in serum by high-performance affinity chromatography, J. Chromatogr. 386 (1987) 37-49.

[23] D.S. Hage, D.H. Thomas, M.S. Beck, Theory of a sequential addition competitive binding immunoassay based on high-performance immunoaffinity chromatography, Anal. Chem. 65 (1993) 1622-1630.

[24] J.A. Anguizola, E.L. Pfaunmiller, M.L. Milanuk, D.S. Hage, Peak decay analysis and biointeraction studies of immunoglobulin binding and dissociation on protein G affinity microcolumns, Methods 146 (2018) 39-45. 
[25] J. Chen, J.E. Schiel, D.S. Hage, Non-competitive peak decay analysis of drugprotein dissociation by high-performance affinity chromatography and peak profiling, J. Sep. Sci. 32 (2009) 1632-1641.

[26] M.J. Yoo, D.S. Hage, Use of peak decay analysis and affinity microcolumns containing silica monoliths for rapid determination of drug-protein dissociation rates, J. Chromatogr. A 1218 (2011) 2072-2078.

[27] M.A. Nelson, A.C. Moser, D.S. Hage, Biointeraction analysis by highperformance affinity chromatography: kinetic studies of immobilized antibodies, J. Chromatogr. B 878 (2010) 165-171.

[28] J. Yang, D.S. Hage, Characterization of the binding and chiral separation of Dand L-tryptophan on a high-performance immobilized human serum albumin column, J. Chromatogr. A 645 (1993) 241-250.

[29] D.S. Hage, High-performance affinity chromatography: a powerful tool for studying serum protein binding, J. Chromatogr. B 768 (2002) 3-30.

[30] J. Anguizola, K.S. Joseph, O.S. Barnaby, R. Matsuda, G. Alvarado, W. Clarke, R.L. Cerny, D.S. Hage, Development of affinity microcolumns for drug-protein binding studies in personalized medicine: interactions of sulfonylurea drugs with in vivo glycated human serum albumin, Anal. Chem. 85 (2013) 4453-4460.

[31] Immunoaffinity chromatography, In: Handbook of Affinity Chromatography Chapter (2006) 6.

[32] A.C. Moser, D.S. Hage, Immunoaffinity chromatography: an introduction to applications and recent developments, Bioanalysis 2 (2010) 769-79o.

\section{Supplemental Material}

Figure S1 shows the valve configuration and valve positions that were used to control the flow of applied solutions and mobile phases in the immunoextraction/entrapment system. Valve 1 was used to control the injection buffer and elution buffer for the immunoextraction column. In position $\mathrm{A}$, the sample was injected into the column, and in position $\mathrm{B}$ the retained HSA was eluted onto a strong cation-exchange (SCX) column. Valve 2 controlled the mobile phase that was used in the SCX column. In position A, HSA that was eluted from the immunoextraction column was retained by the SCX column and in position $B$ the retained HSA in the SCX was eluted. Valve 3 was used to capture the HSA that was eluted from the SCX column. In position B, this valve collected the eluted HSA in a $500 \mu \mathrm{L}$ loop; in position A, the captured HSA was passed through the entrapment column. 


\section{Position A}

Valve 1

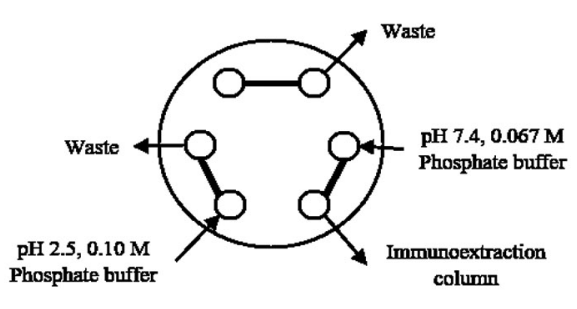

Position B

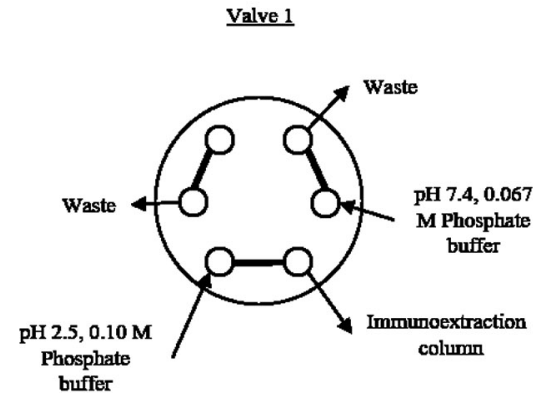

Valve 2

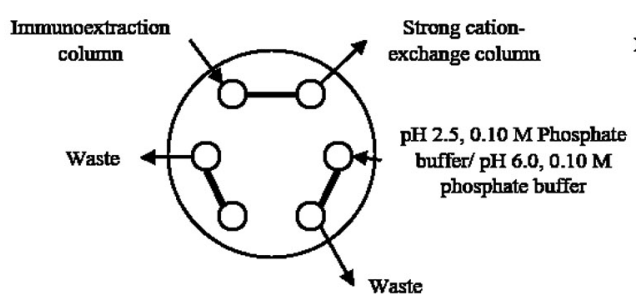

$\underline{\text { Valve } 3}$

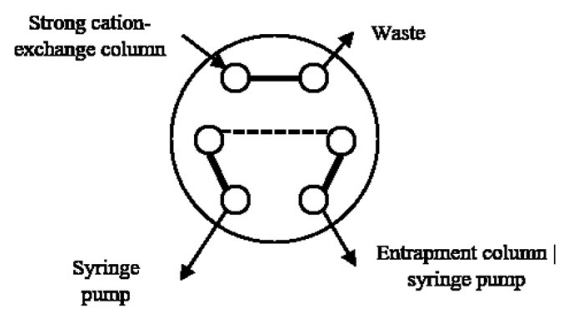

Valve 2

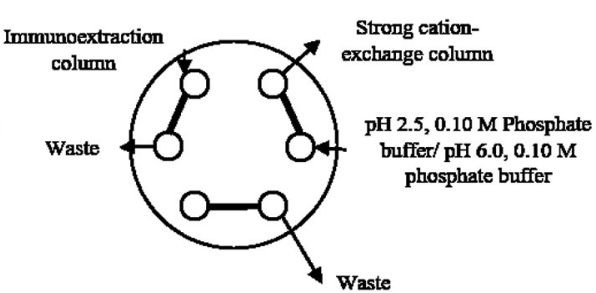

Valve 3

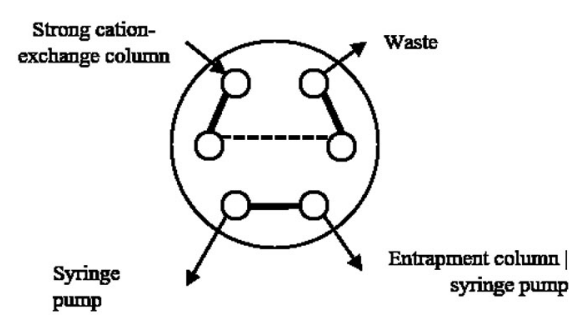

Figure S1. Valve configurations and positions used to control solution and mobile phase flow in immunoextraction/entrapment system. 